\title{
A Case Study of Super City-Complex of English-Speaking Countries - New York Megalopolis
}

\author{
Jia Wang \\ Tianjin University Renai College, Tianjin, China
}

Keywords: New York Megalopolis, Super City Complex, English-Speaking Countries

Abstract: The word 'megalopolis' is deformed from the Greek ' $\mu \varepsilon$ $\gamma \alpha \varsigma \pi$ ó $\lambda ı \varsigma^{\prime}$ ', which means a great city. In 1954, the term was cited by Jean Gottmann, a French geographer, to describe the chain of metropolitan areas along the northeastern seaboard of the U.S., known as the "Bos-Wash corridor" or New York megalopolis. Today, the development of actual megalopolises goes well beyond Gottmann's imagination and expectation. So far, New York is the most advanced and developed man-built megalopolis in the human society. The megalopolis places a great significance on the development and advancement of the surrounding regions and the nation, even the world economy. Considering China's Collaborative Development Plan for Beijing, Tianjin and Hebei, this research provides an in-depth analysis on New York's achievement and experience for decision-makers in China.

\section{Introduction}

Generally speaking, there are at least three megalopolises in the United States, including New York, Chicago and California. There are many specialists and professionals believe that megalopolis will be the most popular way of urban design and development in today's globalised world. As one of the world top five supper city complexes, the impact of New York goes beyond the region. New York plays an important role for the prosperity of the US society and has become the most powerful engine for the world economy. As such, the story of New York needs to be examined closely due to its significance and influence in world super cities. This is especially true when the Central Government of China has introduced its Collaborative Development Plan for Beijing, Tianjin and Hebei.

\section{The Definitions of Metropolitan Area and Megalopolis}

In 1910, the concept of "metropolitan area" was initially introduced in the United States. It is a region that consists of an intensively populated urban-core area and its less populated surrounding territories. It shares industries, infrastructure, and housing. In the first half of the $20^{\text {th }}$ century, there many metropolitan areas spread out across the United States. The Census Bureau gave its official recognition to the term of "metropolitan areas" in the 1910 census. Metropolitan districts were defined on a national wide basis for places with a population of at least 100,000 (Nussle, 2008). There have been several changes to the term, but it generally refers to the region which has a core city with more than 100,000 residents and with certain surrounding areas. 


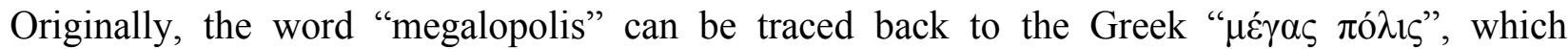
literally means a 'great city'. Later, the term was cited by Jean Gottmann in 1954 to describe a chain of metropolitan areas along the north-eastern coast of the USA, extending from Boston, Massachusetts through New York City, Philadelphia, Baltimore, and ending in Washington, D.C. and Northern Virginia. Gottman believes that a megalopolis should be a huge region where cities and towns are merged together with no distinct difference between the rural area and the urban area. Metropolitan area is a cell unit of a megalopolis, which is a benchmark in the development of human society.

\section{Established Megalopolises in the USA}

In the United States, it is common that the boarders of nearby cities merge with each other. It is possible for small-to-medium-sized cities or towns to be integrated as a larger one. Conversely, large-sized cities may absorb its surrounding satellite cities or towns. It is generally accepted by most scholars that there are at least three megalopolises in the United States of America, here they are, New York, Chicago and California.

Chicago Megalopolis stretches out through four states, including Indiana, Wisconsin, Michigan, and Iowa. Today, it expands its body to the east, including Detroit, Cleveland, and Pittsburgh, covering a land area of 28,120 square kilometres with a population of about 10 million. Chicago is the home for 57 World Fortune 1000 companies' headquarters, including Boeing, McDonald's, Discover Financial Services, and Aon, which together represents different industries and forms a strong engine and backbone for the economic development of the region.

California Megalopolis, with both Northern and Southern areas, contains 9 of the 50 biggest cities in the U.S. Its economic scale is the largest state in the States and the ninth largest in the world. Northern California's Silicon Valley is the home for many world class hi-tech corporations, such as Apple, e-Bay, Yahoo, Facebook, YouTube, Google, and HP. Southern California is the centre for world entertainment industry in motion picture, television, music, and the Hollywood.

\section{New York Megalopolis}

New York megalopolis, or simply New York, refers to a belt area that is located in the northeastern part of the United States and the Atlantic coast, including 40 cities, in which there are five major metropolitan cities of Boston, New York, Philadelphia, Baltimore and Washington, with a urbanisation level of $95 \%$. New York occupies a coastal position on the eastern margin of the continent. The coastline provides more land area close to the sea thus providing greater opportunity for access to cheaper sea transportation. The entire megalopolis has some of the best natural harbours in the America, New York Harbour for example. New York's Lang Island provides a good geographic location for port facilities.

In the megalopolis, New York City plays the role of a core engine. For example, the Wall Street provides financial support during different stages of development. Massachusetts Institute of Technology (MIT), Harvard University, Boston University, and the University of New York provide intelligent support for the talent pool of the region. Washington D.C. offers political support for the design and development of the area. Philadelphia is specialised in clean energy, pharmaceutical and manufacturing industries. Baltimore, an important harbour city along the Atlantic coast, is also a milestone for the renaissance of America's old industrial district. After the end of the "Cold War", the industry structure in Baltimore gradually shifted from the national defense industry to manufacturing and tourism. 


\section{New York's Urbanisation}

Urbanisation is a pre-condition for building up a megalopolis. Industrialisation is the core engine for urbanisation. Productivity is the key to both industrialisation and then urbanisation. In the 1920s, New York City began to extend from downtown to its outskirts. After World War II, local government has done a lot works to support highway construction to catch up with the development of the automobile industry. People began to pour into the suburbs since 1960s when the highway network construction completed. New York's number of populations have always been increasing, from $19,710,239$ in 1990 , to $21,361,797$ in 2000 , and 23,076,664 in 2010. Such a large-scale expansion in the size of population encourages a spread of metropolitan area into a greater range, and eventually leads to the formation of megalopolis.

\section{New York's Transformation in Economic Structure}

New York maintains its position as a global economic centre. The transformation of industrial structure of New York megalopolis is not only about the scale, but a significant upgrade and transform. In the era of post-industrialisation, service sector took the place of manufacturing then becoming the most important driving force of New York's economic growth. In the labour market, jobseekers have shifted from agricultural sector and the manufacturing sector to the service sector, at the same time, show a higher level of professional knowledge and skills. The shortage in the manufacturing industry has resulted in a pay rise in the job market. New York is a creative centre for fashion design and modern art. It is one of the leading cities for international fashion festivals. It is the centre for finance, IT, and service industries. Manufacturing industry, with advanced productivity, remains as an integral part of the new regional economy.

Since late 1970s, there has been a rapid economic expansion domestically and internationally in international trade, financial circulation, cross-border banking, and international aviation. By 1986, 40 out of the top 100 multinational companies have established their headquarters in New York. For these companies, one third of their total income came from foreign business and the gross income reached 137 billion dollars. New York also performs very well in financial market and stock market. By 2010, 191 foreign banks have established their offices in New York, and their assets are boosted up to $\$ 238$ billion dollars. Moreover, they created 27,000 jobs. At the end of $2010,11.4 \%$ of the local workforce worked in finance, insurance, and real estate sectors. Meanwhile, the proportion of those who engaged in consulting, healthcare and education services was as high as $23.4 \%$.

\section{New York's Transportation System}

New York's public transportation facilities refer to railroad terminals, airports, seaports tunnels, bridges and so on (New York Metropolitan Transportation Council, 1995). Rail transit plays an important role in the public traffic system of New York megalopolis with a proportion of 51.57\% of its total transportation capacity. New York Metropolitan Region Subway is the rapid mass transit system and one of the most complex and historical underground railway systems. The total length of rail reaches 842 miles. The data shows that 468 stations are running now, covering a length of 656. Among them, 229 miles are under commercial operations.

New York Megalopolis has a huge need of transit since the frequent exchanges in products and passengers. The multi-level mass transit system in this region meets the needs with its advantages of punctuality, safety, and high speed. As for the rail transit system, it can be further divided into three parts, namely the regional rail, commuter rail, and the mass rapid transit. Regional rails were built to connect different cities in the megalopolis. Stations were established in the core city and other big cities in the region so as to keep a high speed. Its advantage lies in the quick connection 
between cities. Commuter rail is also known as suburban rail. It was built to connect the core city and the suburban areas. Most of the passengers are the commuters who live in the suburb while work in the downtown area. Commuter rail improve influence of the core city and expand the edge of megalopolis step by step. Mass rapid transit focuses on short trips in the downtown area. Usually, it will combine with other transit forms through hub or interchange station.

In addition to rail transit, bus system is one other essential means for mass transportation. Stateowned and private buses account for $35.83 \%$ of the mass transit system. In the megalopolis, buses and subways are combined to form a network with easy transfers. Metropolitan Transit Authority is responsible for the operations and management of the bus system. There are roughly 5,800 buses with more than 20,000 passengers travel around by 200 ordinary lines and 301 express lines. New York megalopolis gives priority to the development of the public transportation. Many policies are carried out to encourage people to take buses, instead of driving private cars. At the same time, the government also controls the usage of private cars through fuel taxes and transit fees.

According to the 2010 American Community Survey, 54.3\% of the interviewed commuters used a car or other private vehicle alone; another $7.0 \%$ used a carpool. While those who used public transportation account for $27.0 \%$. It is safe to say that private car is still the top choice when travel short distance. Many proposals for creating an auto-free zone in metropolitan areas are advanced. A survey of the Boston SMSA concerned a plan to ban all automobiles from downtown Boston. The results indicate wide acceptance of the idea provided that any necessary funding would not come from new taxes. If the plan were to be put into effect, the number of trips to downtown Boston would increase. Those persons who presently travels by private cars would continue to drive as close to the downtown area as possible (Pfeiffer 1985).

\section{Efficient Division of Labour}

Industrialisation physically divides land for different uses: natural conservation, agriculture, residential zoning, business zoning, traffic and recreation. This kind of distribution is especially important when it comes to the megalopolis. How to make full use of the scarce land resources to create maximum economic profits is the key.

New York megalopolis is structured by a three-level pyramid structure. New York City sits at the top the pyramid. 4 large scaled cities, Boston, Washington DC, Philadelphia, and Baltimore form the main body of the pyramid. More than 40 small and medium-sized cities lays at the bottom of the pyramid.

New York City became the core city with its advantages in science and technology innovation, venture capital as well as industrial structure. Meanwhile, other cities also get their own opportunities to make a progress. Boston is famous for its high-tech and education industries. Philadelphia is well known for its medicine, aviation, and electronics industries. Mining and shipping industries are the pillar for Baltimore. Each of the core cities has their own independent leading industry, they play an integral function in the megalopolis. The combined influence is much greater than the sum of each city. This kind of diversity enlarges the complementary effect among the cities, thereby enhancing the economic stability of the entire megalopolis.

The industrial upgrading of New York megalopolis during the 1970s and 1980s is the case. In this period, manufacturing suffered depression while the financial service industry enjoyed a blossom in New York City. As a result, financial service took the place of manufacturing to take the leading role in economic growth while manufacturing was transferred to the surrounding cities. Similarly, in Boston, high-tech industries forced the manufacturing section to withdraw from the downtown area and moved to the southern part of the city. 


\section{Consistent Innovation}

The most valuable part of New York megalopolis lies in consistent innovation. This is clear in the speech of Michael Bloomberg, the former mayor of New York City. He said: "Anecdotally, we know there has been a big uptick in innovation activity in New York City, but now we're also seeking to quantify our progress. By partnering with academia and venture capitalists, we'll become the first major city in the country to create an Innovation Index.". The index will track New York City's performance in several key areas, including VC investment, federal research grants received, employment in the fields of science and engineering, new patents and the commercialisation of technology of the local universities and research institutions. This data will help the New Yorkers focus efforts on innovation and refine the strategies and policies they use to promote it.

\section{Breaking Down Trade Barriers}

Under the market mechanism, competition among cities is inevitable. Therefore, coordination mechanism is introduced into the megalopolis to control immoderate competition to make sure that each city can make full use of its own advantages, while making contribution to the megalopolis. According to the regulations of Regional Plan Association, each city has its own objectives. Meanwhile, they share some common tasks. Moreover, under the concept of sustainable progress, the previous three regional plans have established short-term, medium-term and long-term goals respectively.

For multi-core megalopolis like New York, conflicts among the central cities are a serious issue. The evolution of New York megalopolis shows that it is possible for each central city to keep its own features through taking advantages of its preponderant industries. At the same time, coordinate development also means keeping a good relationship among the cities at various levels, such as the relationship between the central city and the satellite cities, as well as the relationships among the satellite cities.

\section{Conclusion}

As the largest megalopolis in the world, New York megalopolis has come into the research field of many experts. Many governments and administers also regard it as a model of management. This thesis has focused on the key driving forces of economic growth in the region.

The megalopolis places a great significance on the development and advancement of the surrounding regions and the nation, even the world economy. In light of China's Collaborative Development Plan for Beijing, Tianjin and Hebei, this research provides an in-depth analysis on New York's achievement and experience for decision-makers in China.

\section{References}

[1] American Public Transportation Association (APTA). (2014). Transit Ridership Report Fourth Quarter and End-of-Year 2014.The USA: APTA.

[2] Gottmann J. (1961). The Urbanized North-eastern Seaboard of the United States. The USA: Twentieth Century Fund.

[3] New York Metropolitan Transportation Council. (1995). We are a region: A report for the Long Range Plan. USA: New York Metropolitan Transportation Council.

[4] Nussle, Jim. (2008). Update of Statistical Area Definitions and Guidance on Their Uses. The USA: Office of Management and Budget.

[5] Pfeiffer, D. (1985). Public Attitudes Toward an Auto-Free Zone in a Metropolitan Area. International Journal of Public Administration, 7(1), 51-66. 